\title{
Shade coffee and amphibian conservation, a sustainable way forward? Understanding the perceptions and management strategies of coffee growers in Colombia
}

\author{
$\underline{\text { Nicolette S. Roach }}^{1,2}$, Daniela Acosta $^{3}$ and Thomas E. Lacher, Jr. ${ }^{1,2}$
}

\begin{abstract}
Understanding the perceptions and management practices of local land users is critical to improve conservation programs and sustainable outcomes. Colombia, one of the most megadiverse countries in the world, is also the third largest global producer of coffee. Cafeteros (rural coffee farmers) produce the majority of Colombian coffee. The Sierra Nevada de Santa Marta (SNSM), Colombia, is an isolated mountain on the Caribbean coast and one of the world's most biodiverse regions. Coffee grows in agroforestry matrices alongside high levels of endemic amphibians. Our goal was to understand (1) the perceptions of cafeteros about biodiversity, and (2) how coffee management practices may impact amphibian conservation in the region. We selected coffee communities that were close to concurrent amphibian research sites, to conduct focus groups. Themes, focused on both conservation and development, emerged from the five focus groups, specifically conservation program design and livelihood constraints. These were broken down into generic categories and subcategories ranging from cafetero knowledge of biodiversity and climate change to socioeconomic constraints. We found that although cafeteros have an inherent appreciation for the landscape and conservation, they require economic support to achieve sustainability goals. We recommend three steps to improve sustainability and equitable practices in the SNSM: (1) alleviate the economic strain on local coffee growers through social and economic government programs; (2) improve distribution of updated technology and coffee processing methods and to farmers; and (3) connect local farmers directly with buyers.
\end{abstract}

Key Words: biodiversity; cafetero; climate change; conservation; shade coffee; sustainability

\section{INTRODUCTION}

Long-term conservation implementation is rarely successful without the support and engagement of local communities (Bennett et al. 2017). One barrier to enacting conservation action is a lack of understanding of local community perceptions on conservation issues (Bennett 2016). Land users participate in the extraction or alteration of natural resources on small scales and the management of these private and surrounding landscapes has direct impacts on species conservation (Hudson et al. 2014). Globally, small-scale farmers (those with holdings $<5$ ha) make up approximately $87 \%$ (Nagayets 2005, Lowder et al. 2016) of agricultural shareholders. Across the tropics, agriculture has contributed to habitat loss and homogenization of biodiversity (Gallmetzer and Schulze 2015, Nowakowski et al. 2018, Menéndez-Guerrero et al. 2020). Pending management practices, small-scale farmers can have lower environmental impacts on their landscape (Perfecto et al. 2019). Understanding the local land user's perceptions of biodiversity and conservation and how these integrate with management practices can help improve collaborative conservation efforts (Bennett 2016).

There is evidence that sustainable agricultural practices can be less detrimental to biodiversity (Perfecto and Vandermeer 2008), mitigate climate impacts (Andrade and Zapata 2019), and benefit local community members (Tscharntke et al. 2015, Solano et al. 2017). Colombia is the third largest global exporter of coffee (International Coffee Organization 2020). Agricultural production occurs in mountain habitats across the Colombian Andean chains to the isolated Sierra Nevada de Santa Marta (SNSM). These mountain ranges support immense global biodiversity and endemism (Myers et al. 2000, Ocampo-Peñuela and Pimm 2014, Agudelo-Hz et al. 2019). Current agricultural practices threaten biodiversity through the degradation of landscapes and watersheds, overexploitation, deforestation, and forest fragmentation (Etter et al. 2006). The tropical Andes are also threatened by climate change, as the steep elevational gradients support transitions across multiple ecosystem types, which are geographically restricted and highly susceptible to rising temperatures (Herzog et al. 2011). Concerns for biodiversity conservation are driven by combined climate change and habitat loss, specifically, increases in agricultural intensification and shifts of production into previously undisturbed habitats (Leclère et al. 2020).

In Colombia, coffee is grown in montane regions and overlaps with areas high in species endemism and biodiversity (Bernal and Lynch 2008, Hoyos-Hoyos et al. 2012, Roach et al. 2020). A major agricultural crop, coffee is grown two ways: in the sun or in the shade. Sun coffee, a popular option in Brazil, is grown without the presence of any other crops or trees; in this case coffee is a monoculture crop. Shade grown coffee, a more sustainable option, is grown amidst large nitrogen-fixing trees, creating a forest-like canopy. Shade coffee provides heterogeneous vegetative structure, increases habitat complexity, and is the preferred agroforestry landscape for biodiversity conservation, over monoculture crops (Perfecto and Vandermeer 2010). Although shade coffee appears to benefit some species (Murrieta-Galindo et al. 2013, Caudill and Rice 2016, Guzmán et al. 2016, González et al. 2020), results across taxa are mixed, and dependent on the vegetative structure and management practices of the shade coffee agroecosystem (Philpott et al. 2008, Otero-Jiménez et al. 2018, Narango et al. 2019, Roach et al. 2020). 
Resource use and land use change are intertwined with territories, historical contexts, and geographic landscapes (Zimmerer 2002). The majority of coffee production in Colombia is from smallscale farms (Farfán Valencia 2014). Coffee farmers, or cafeteros, focus on growing, harvesting, and exporting coffee and are one of the main agricultural land users in the country. Cafeteros are completely dependent on their land, making them vulnerable to climate impacts and the instability of global market prices (Hannah et al. 2017, Villarreal 2018, Andrade and Zapata 2019, Montgomery 2019). The intensity of agricultural land management is an important factor in sustaining biodiversity and low intensity management practices are preferred (Perfecto and Vandermeer 2008, Haggar et al. 2011). Agricultural practices can have perverse effects on montane species and endemics because of species' limited dispersal and adaptation capabilities (McCain and Colwell 2011, Menéndez-Guerrero et al. 2020). In Colombia, cafeteros manage their coffee plantations through fumigation, fertilization, burning, and clearing understory growth from coffee plants.

This study took place in the Sierra Nevada de Santa Marta (SNSM), Colombia, where $95 \%$ of the coffee is shade-grown on farms of less than five hectares (Farfán Valencia 2014), in an agroforestry matrix that is promoted as biodiversity friendly. Coffee is picked by hand during cosecha (harvest), October to March. The length of cosecha is variable, dependent on the elevation and yearly precipitation and temperature patterns. Environmental laws dictate a 30-m natural vegetation buffer along major waterways (Decree 2811, 1974), including fines for those that do not comply or that dump unprocessed wastewater on land or into waterbodies (Decree 2667, 2012); yet these laws have yet to be enforced in the region. In the SNSM, management practices are varied and there is a mix of pesticide and fertilizer use among both organic and non-organic farms. Many coffee wastewater systems are drained back into the landscape without being processed through filtration systems. The responsibility to maintain clean watersheds falls largely on local communities who receive little assistance from government authorities. This leaves watersheds at risk of unregulated wastewater dumping and contamination from trash and septic tanks.

This unregulated wastewater contamination, combined with a decade of low global coffee market prices, disease outbreaks (coffee leaf rust), and climate instability (Avelino et al. 2015, Hannah et al. 2017, Läderach et al. 2017) poses challenges for cafeteros and surrounding landscapes in Colombia's various coffee growing regions. In the SNSM, coffee is the main source of income for small-scale cafeteros. At the time of this study (2017-2018) coffee prices hit their lowest level in 10 years (International Coffee Organization 2018). Low economic gains make it difficult for cafeteros to maintain coffee crops as climates change. Future concerns of climate impacts on Colombia's biodiversity (Flechas et al. 2017, Agudelo-Hz et al. 2019, Menéndez-Guerrero et al. 2020), agriculture (Ramirez-Villegas et al. 2012, Andrade and Zapata 2019), and livelihoods (Múnera and van Kerkhoff 2019) further threaten these agroforestry matrices.

Mismanagement of landscapes can have negative impacts on local biodiversity. Amphibians, which are particularly sensitive to environmental degradation, are of special concern (Mann et al.
2009). The SNSM boasts high levels of amphibian endemism and local community observations can provide important ecological knowledge about microclimates, species' population dynamics, habitat use, and local extirpations (Granados-Peña et al. 2014). In addition, understanding the priorities and perspectives of cafeteros can inform management and help enact appropriate conservation strategies (Sawchuk et al. 2015, Bennett et al. 2017) by including new ecological knowledge (Brook and McLachlan 2008, Joa et al. 2018) and an understanding of local climate patterns (Thornton and Maciejewski Scheer 2012, Mwenge Kahinda et al. 2019). It was important for us to understand the perceptions of cafeteros about biodiversity and to further hypothesize why amphibians appeared absent from coffee plantations during our concurrent research (Roach et al. 2020). We were broadly interested in questions related to cafeteros' knowledge of biodiversity and wildlife, what they valued about their landscape and livelihoods, and if climate change had impacted their livelihoods. We wanted to improve our understanding of (1) the perceptions of cafeteros about biodiversity and the local ecosystem, and (2) how coffee management practices may impact amphibian conservation in the region. We hypothesized that management practices of coffee may conflict with important life history periods for amphibians, the focal organism of our ecological research in the region (Roach et al. 2020). Through the integration of the perspectives of cafeteros with amphibian conservation we hoped to gain insights in ways we could enact collaborative conservation plans that would sustain both biodiversity and the permanency of local livelihoods.

\section{METHODS}

\section{Site selection}

Our research took place in the Sierra Nevada de Santa Marta (SNSM), department of Magdalena, Colombia (Fig. 1). The SNSM is a globally important area for biodiversity and a distinctive cultural coffee region in Colombia, focused on certified sustainable production (Comite de Cafeteros Magdalena 2021). It has been designated a key biodiversity area, Alliance for Zero Extinction site, UNESCO Biosphere Reserve, and contains two national parks (Sierra Nevada de Santa Marta and Tayrona). It is also a global hotspot for amphibian endemism and was ranked the most irreplaceable site for threatened species in 2013 (Le Saout et al. 2013). Deforestation has left the landscape patchy with reduced habitat connectivity (Granados-Peña et al. 2014). Land above $2500 \mathrm{~m}$ is indigenous territory and a national park (SNSM $\mathrm{NP}$ ), whereas land under $2500 \mathrm{~m}$ is largely a mixed-agricultural matrix interspersed with private nature reserves and ecotourism development.

In the department of Magdalena, there are four coffee growing regions: Aracataca, Ciénaga, Fundación, and Santa Marta. Working with extension agents from the Federación Nacional de Cafeteros (FNC) we selected coffee farming communities based on geographic proximity to concurrent amphibian field research sites, as well as where FNC extension agents offered their help with the organization of focus groups. The FNC coordinated the logistics of the focus groups including organizing participants, location, time, and date. We surveyed five coffee communities (Palmor, Plan de las Ollas, San Javier, San Pedro, and Vista Nieve) across two coffee growing regions: Ciénaga and Santa Marta. These five locales were adjacent to concurrent amphibian research 
in the region (Roach et al. 2020). The department of Magdalena contains 5200 coffee farms and over 20,000 ha devoted to coffee production (Federación Nacional de Cafeteros 2009; Fig. 2.). Coffee is grown along mountain ridges (from 600 to $2000 \mathrm{~m}$ ), where crops occur on steep slopes sometimes over 45 degrees. The terrain is rugged and transportation limited and most cafeteros use mules to transport their crops.

Fig. 1. Site map showing the study region in Colombia, South America (L) and the full extent of the Sierra Nevada de Santa Marta, Colombia, and the location of the studied coffee growing regions ( $\mathrm{R})$. The teal is the Santa Marta coffee growing region and the orange is the Ciénaga coffee growing region where focus groups were conducted. The city of Santa Marta is denoted by a purple dot.

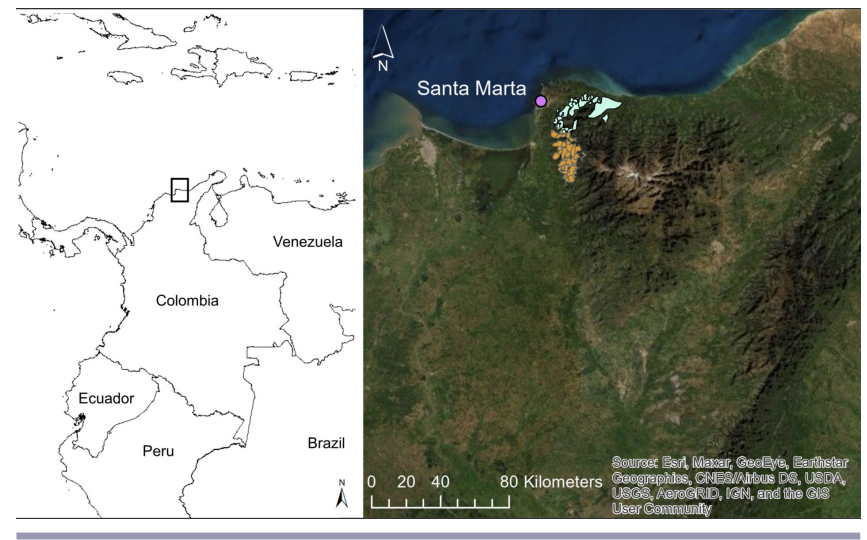

Fig. 2. Coffee habitat and processing in Sierra Nevada de Santa Marta. (A) San Pedro community and coffee below ridge; (B) shade coffee farm; (C) coffee drying on a farm in San Pedro; (D) Coffee going through the de-pulping and washing process.

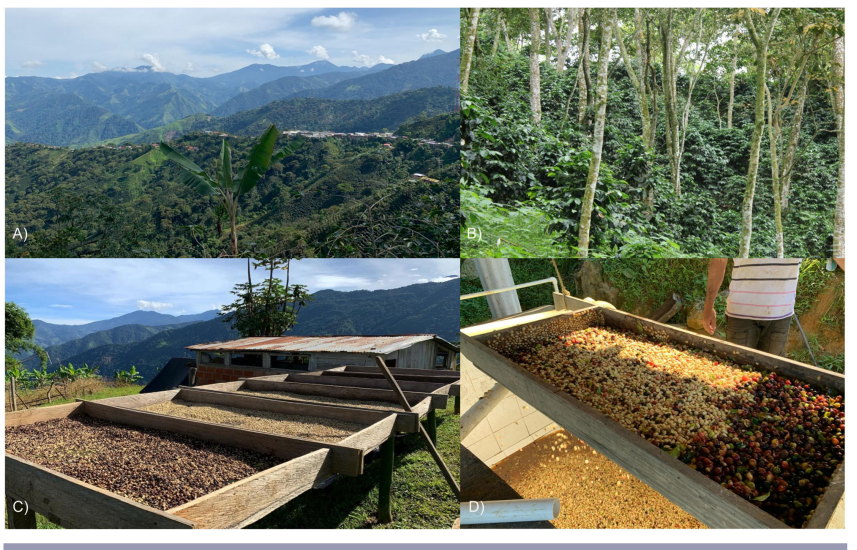

Institutions: Federación Nacional de Cafeteros (FNC)

The FNC (https://federaciondecafeteros.org/) is a private organization that was formed in 1927 with a mission to look after the welfare of cafeteros through an effective trade union and democratic and representative organization. The FNC provides a number of services to farmers including, (1) guarantee of purchase, FNC will buy coffee from cafeteros regardless of the year, or current market prices; (2) promotion of the consumption of Colombian coffee; (3) scientific research and technology through the Centro Nacional de Investigaciones de Café (Cenicafé); (4) extension agent services; (5) management of local, regional, and international alliances and projects; (6) quality guarantees of Colombian coffee. Cenicafé is responsible for developing new technologies ranging from disease resistant and climate change tolerant plants to filtration systems to reduce contamination in coffee wastewater. The FNC utilizes the extension agent service to provide advances from Cenicafé to cafeteros. The FNC has a national sustainability development plan, including development objectives in four areas: economy, governance, environmental, and social (Federación Nacional de Cafeteros 2015).

\section{Focus groups}

To better understand the knowledge and perceptions of cafeteros, we chose to conduct focus groups (ranging from 7 to 16 people/ group), which would provide us with baseline information to help guide future ethnographic studies and conservation program design. Focus groups allow researchers to engage in informal discussion with a small number of people focused on a particular set of issues (Krueger and Casey 2000, Wilkinson 2004, Onwuegbuzie et al. 2009). The open-ended questions allow researchers to obtain data that present the participant's wording and allow for participants to build on each other's ideas, potentially providing new information to the moderators (Stewart et al. 2009). Additionally, the presentation of results of focus groups are easy to understand for both researchers and decision makers. Focus groups help collect data rapidly, which was useful for our pilot project. In the SNSM, farmers live far from centralized locations and farms may be inaccessible to most researchers. We were able to manage time and limited resources better for both cafeteros and researchers who have to travel long distances. Finally, we attempted to address any limitations presented in a focus group by recording information on the number of participants who spoke during the focus group, and by having two independent moderators who assessed responses. Our goal was to obtain preliminary information that would be useful for future research design and implementation on similar topics.

We recruited members for focus groups through the FNC. The FNC extension agents recruited participants for the focus groups from each respective community. Focus groups took place on one of the participant's farms or a neutral space, such as a local tienda (store). Focus groups lasted two to three hours and were conducted in Spanish and later translated to English for ease of analyses. In October 2017, we conducted an exploratory focus group in the community of San Javier. This focus group allowed us to identify how group conversations were organized, how to structure the discussion, and how to expand or adjust our a priori questions (Appendix 1). We then made slight changes to the questions we asked the subsequent four focus groups and initiated the coffee calendar with the remaining groups to identify key management practices throughout the calendar year. The remaining four focus groups took places during June-July 2018.

We interviewed a total of 48 participants across all five focus groups (Table 1). Participants were both male (38) and female (10) and adults ( $>18$ years). Some children were present during the 
interviews with their families, but did not participate in the discussion. We asked a series of pre-prepared, open-ended questions related to biodiversity and conservation, climate change, sustainability, history of the region, livelihoods, and the current and future challenges to coffee farmers (Appendix 1). For purposes of our study, we defined livelihoods as in Chambers and Conway (1992), "the capabilities, assets ... and activities for a means of living." Approximately two-thirds of the participants were farm owners and managed their own landscapes, while the remaining one-third of participants were administradores and acted as land managers for the owners who lived in nearby cities.

Table 1. Information about focal group demographics and landscapes.

\begin{tabular}{llccc}
\hline \hline Municipality & Community & $\begin{array}{c}\text { Elevation } \\
(\mathrm{m})\end{array}$ & $\begin{array}{c}\text { Participants } \\
(\mathrm{n})\end{array}$ & $\begin{array}{c}\text { Date of Focus } \\
\text { Group }\end{array}$ \\
\hline Ciénaga & Palmor & 1076 & 17 & June 2018 \\
Santa Marta & Plan de las & 950 & 8 & June 2018 \\
& Ollas & & & \\
Ciénaga & San Javier & 1530 & 7 & October 2017 \\
Ciénaga & San Pedro & 1418 & 10 & July 2018 \\
Santa Marta & Vista Nieve & 1087 & 8 & July 2018 \\
\hline
\end{tabular}

Each focus group had two moderators and one FNC extension agent present during the interviews (with the exception of San Pedro where no extension agent was present). It is important to note that the presence of extension agents may have hindered the honesty of responses from participants. Throughout the interviews we allowed for the conversation to flow and asked follow-up questions dependent on the answers given earlier in the focus groups (Patton 2002). After each focus group, the moderators gathered and answered a series of reflection questions and discussed any prevalent themes that emerged during the focus group. Data were reviewed and revised by two persons. Here moderators reflected independently on what each focus group discussed and wrote down observations including how people interacted with each other to how much time they spent on a particular topic.

Our analytical approach was selected to derive categories and subcategories from the notes of the focal group discussion, and use that content to develop a model of the relationship between coffee communities and the natural environment. We conducted a content analysis to examine the categories and themes that emerged across focus groups (Krippendorff 1980, Schreier 2012). A flexible tool, conventional or qualitative content analysis (QCA) allows researchers to decide how to organize data through a coding framework (Hsieh and Shannon 2005, Bernard 2006, Elo and Kyngäs 2008, Cho and Lee 2014). Our approach was to use a deductive analysis to develop a conceptual model to examine our hypothesis based upon qualitative focal group data. We developed a classification matrix to code data into different content-related categories we a priori proposed as relevant based upon knowledge of the region and communities. Coding was done manually, given the sample size of five communities, by the authors. We used deductive structure to analyze the data and created subcategories, generic categories, and main categories to document emergent themes across focus groups (Elo and Kyngäs 2008). In addition, we used inductive approaches to better relate needs and perceptions that emerged during the focal group discussions with community members into the overall final model (Cho and Lee 2014). Using this information, we make recommendations for engaging in conservation and sustainable projects in the region that are derived from the perspectives of the cafeteros.

\section{Coffee calendar}

In a separate analysis, to better understand how land management practices could impact amphibian conservation, we had cafeteros create a "coffee calendar." This exercise was separate from the focus groups and conducted after the focal group discussion; however, calendars were created by groups ( 4 calendars total, excluding San Javier). The calendar highlighted the various activities cafeteros were involved in during specific temporal periods, including periods of intensive land management practices. We analyzed the data by organizing the activities by community and reviewing how many communities participated in similar activities across the temporal scale of one calendar year. We aimed to use this calendar to identify periods of conflict with species life history strategies and/or conservation opportunities. Understanding the local land management practices helps gain a better picture of the challenges conservation programs may face when considering the impacts of both biodiversity conservation and livelihoods.

\section{RESULTS}

Two main categories, or themes, emerged from the QCA: conservation program design and livelihood constraints (Fig. 3). Results for generic categories contain their respective subcategories. Below we present the relevant components of the generic categories for conservation program design (natural resources and land use management) and livelihood constraints (infrastructure and socioeconomic constraints; Fig. 3). The insight gained from the cross-cutting themes and the site-specific conditions (Appendix 2) determines the kinds of conservation interventions that are possible, and influences the likelihood of the implementation. We also present results for the coffee calendar (Fig 4.).

Fig. 3. Results of the qualitative content analysis, expressed as a flow chart of subcategories, generic categories, and main categories based on responses from the five focus groups.

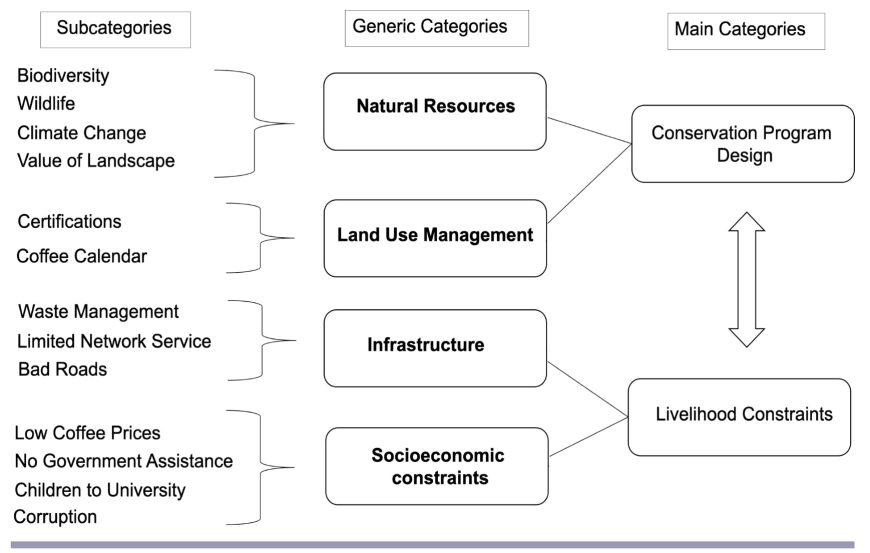


Fig. 4. Coffee calendar from four communities (Palmor, San Javier, San Pedro, and Vista Nieve). Activities during the rainy season (amphibian reproductive season) are outlined in black box. Activities "dry, plant, harvest, clean, fertilize, and sell" relate to coffee plantations and crops, while "other crops" relates to time periods planting or harvesting additional crops, and "roads" relates to road maintenance done by local community members.

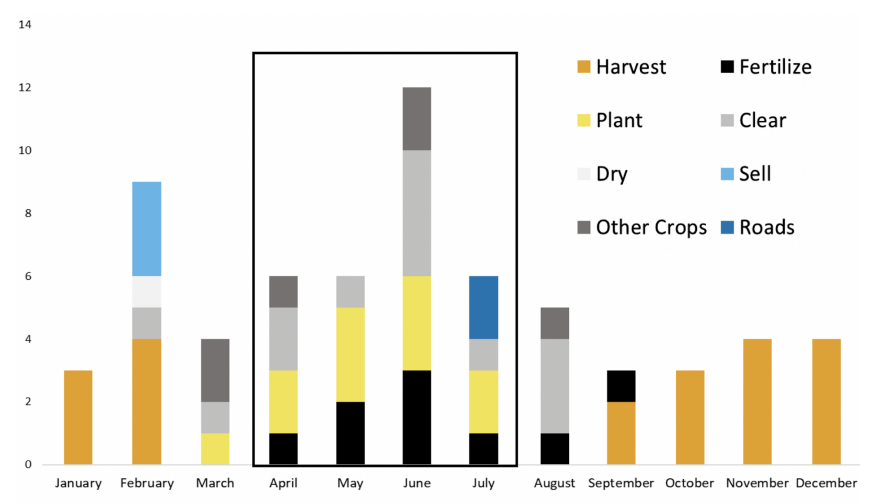

\section{Natural resources}

\section{Defining biodiversity}

Across all focus groups, participants were able to define biodiversity as relating to wildlife and plants. Common responses included: "biodiversity was everything in the ecosystem," "everything found in the land or environment," and "all the species of flora and fauna." Participants often included pastures and farms in their definition of biodiversity.

\section{Wildlife}

Participants were particularly knowledgeable about wildlife on their land. The most commonly discussed species were mammals and birds. In Plan de las Ollas, respondents commented on animal behavior, noting that frogs were found mostly near streams and could be heard calling at night. They provided descriptions of specific frogs, such as Ikakogi tayrona, an endemic species. Additionally, this focal group noted the animal breeding seasons, diet preferences, and interspecific interactions amongst bird species.

Across all focal groups, the primary mammal species mentioned included agouti (Dasyprocta punctata), howler monkey (Alouatta seniculus), deer (Mazama spp.), cats (mostly jaguar Panthera onca but also puma Puma concolor), and armadillos (Dasypus novemcinctus). Lesser mentioned mammals included foxes (Cerdocyon thous), tigrillo/oncilla (Leopardus tigrinus), squirrels (Sciurus granatensis), and pigs (Sus scrofa). Common bird species were Toucans (Ramphastos sulfuratus) and Macaws (Ara spp.), Sickle-winged Guan (Chamaepetes goudotii.), Black-chested Jay (Cyanocorax affinis), and the Crested Oropendula (Psarocolius decumanus).

The only amphibian that was exclusively discussed by at least two groups was the rana platanera (Boana boans), a common species found in agricultural zones. Some participants were familiar with the rana cristal (Ikakogi tayrona) and Colostethus ruthveni, a small species that calls throughout the day, and is found in degraded habitats including adjacent streams and forests within coffee plantations (Roach et al. 2020). Respondents were more likely to note the presence of reptiles, specifically snakes (it is common to encounter snakes during cosecha), including the fer de lance (Bothrops asper) and coral snake (Micrurus spp). A few respondents stated that they only killed venomous snakes. However, we did not obtain information on their ability to correctly identify venomous vs. non-venomous snakes.

\section{Climate change}

Each focus group observed changes in the local climate over the last 10-30 years. Participants in the Palmor group observed a decrease in water and ice, and less annual rain but higher storm intensity: "in just one day we will get all the water that used to fall in one week." They also observed hotter local temperatures and stated coffee was now grown at higher altitudes (1700 m vs. $1200 \mathrm{~m}$ ).

The group from Plan de las Ollas noted that 25-30 years ago, the closest town used to be cold and "people wore jackets, hats, and had blankets. Now it is hot and people use fans." They also observed changes in precipitation patterns, including a reduction in the rain frequency. Finally, participants mentioned that, because of changes in climate, coffee must now be planted at specific times of the year that are different from previous temporal periods.

In San Javier, participants noted higher frequency and intensity of precipitation events that often damages the coffee fruit and results in economic losses for cafeteros. Dry seasons are now shorter, which made it difficult for coffee to mature. In San Pedro, participants observed changes to avian ranges, specifically species that had moved higher in elevations. They also observed lower water availability and drier streams. As a result, some cafeteros discussed crop switching to avocado or mango.

Similarly, participants from Vista Nieve observed changes in precipitation patterns and an increase in temperatures. They also observed shifts in elevational ranges and behavior for bird species, specifically noting that the Bicolored Wren (Campylorhynchus griseus) and Great-tailed Grackle (Quiscalus mexicanus) had demonstrated aggressive interactions. Finally, they stated their coffee production was irregular because there was often too much sun or rain.

\section{Value of landscapes}

Cafeteros place an inherent value on their land (coffee) and the surrounding landscapes (water and conservation). The majority of participants commented on the global importance of the SNSM, particularly its uniqueness. Four of five groups named water and the maintenance of watersheds and microcuencas (small watersheds or streams) as the most valued factor in the landscape. Apart from water, group values mostly focused on the land and conservation. The Palmor group valued coffee and future growing viability; while the group from Plan de las Ollas valued the tranquility of the SNSM. The San Pedro group stated that "doing conservation and taking care of the land"was the most important thing. They also desired technologies that were less detrimental to the environment. The Vista Nieve group was also interested in conservation and restoration of habitat and how they could 
reduce contamination. Finally, all focal groups indicated that people worked to conserve watersheds and understood the importance of the SNSM, and that their own land (specifically coffee plants) were the most important.

\section{Land use management}

\section{Certifications}

Around half of the participants had at least one type of certification ranging from organic to fair trade or socially responsible. Organic certifications included Colombian specific certifications like EcolRed and ColCafé to globally recognized programs like Rainforest Alliance. It can take up to three years to prepare a farm to become organic; cafeteros noted this process was economically costly and labor intensive. Participants discussed disadvantages of organic farms including susceptibility to plagues and disease because they are unable to apply insecticides or pesticides. Organic growers reported selling coffee at slightly higher prices, but the margin of a 12 to $15 \%$ increase for organics is only viable if there is no significant loss of productivity due to reliance on organic fertilization and pest control. Organic farms are also more susceptible to disease, like broca, the coffee berry borer (Hypothenemus hampei), that has decimated plants across the globe (Damon 2000). Because organic certifications prohibit the use of chemical fertilizers and pesticides, some farmers choose not to participate in these programs in order to produce more coffee.

\section{Coffee calendar}

Four communities provided information for the coffee calendar: Palmor, Plan de Las Ollas, San Pedro, and Vista Nieve. The coffee calendar highlights the main land management practices during the 12-month calendar year (Fig. 4). The temporal period of activities across communities varied slightly, most likely because of differences in elevation, topography, and precipitation. Notably, land management practices (such as application of fertilizers and herbicides, clearing of understory by machetes or burning, and planting other crops) intensify during the rainy season, a critical reproductive time period for amphibians. During cosecha, additional water from nearby streams or wells are used to process the coffee. Cosecha also requires an influx of people on the landscape to hand-pick coffee.

\section{Infrastructure}

Each focus group emphasized the desire for improved transportation, communication, and technology systems (such as the beneficiadero or the coffee processing system). Across groups a main concern was road accessibility. Most roads are unpaved and may be impassable during the rainy season. Participants in Palmor discussed that some roads could not be improved because they are resguardos indigenas (Indigenous private property, as decreed in the Colombian constitution). Finally, trash disposal is a problem for many residents and it is common to burn and bury trash.

\section{Socioeconomic constraints}

Low coffee prices are the largest concern for cafeteros in the SNSM. Cafeteros want to sell their coffee for higher prices and directly to buyers instead of going through filters of organizations and cooperatives. Cafeteros also mentioned they would like access to other economic opportunities such as Ecotourism (Palmor, Plan de las Ollas, Vista Nieve, San Pedro). In Plan de las Ollas and Vista Nieve, cafeteros were concerned about the future of their coffee farms citing a lack of generational interest in the practice of growing coffee.

Finally, most of the groups complained about lack of government support. In Vista Nieve a deep mistrust of the local environmental authority has left community members frustrated and angry. Participants also stated that some community members accept bribes. Both San Pedro and Vista Nieve discussed previous researchers coming to the region and never sharing results with the community, leaving them feeling frustrated and skeptical of outsiders. Throughout the region, the history of conflict has made cafeteros livelihoods uncertain; the San Javier focus group, spent about 30 minutes discussing the armed conflict including illegal land seizures and lack of safety in the region.

\section{DISCUSSION}

We aimed to better understand two aspects of the relationship between cafeteros and the agroforestry matrix of the SNSM: (1) the perceptions of cafeteros about biodiversity and the local ecosystem, and (2) how coffee management practices impact amphibian conservation. Perceptions can provide insights on how best to interact with local communities regarding conservation initiatives, and when assessed in combination with a clearer understanding of current management practices, will improve conservation planning (Bennett 2016, Bennett et al. 2017). Cafeteros in the SNSM are knowledgeable about biodiversity, wildlife, and local climatic patterns. They have a strong appreciation of the value of the landscape and understand the importance of taking care of their land. Many view their coffee plantations and pastures as a component of biodiversity. This suggests that conservation initiatives need to appreciate the mingling of natural and production landscapes, and seek ways to mitigate biodiversity loss without impacting livelihoods. A shared value for the importance of water was present in four of the five focus groups, which emphasizes potential for collaborative studies that link human and environmental health to agriculture management techniques. In addition, local communities closely experience the effects of a changing climate, and clearly acknowledge the fact. Cafeteros have an interest in improving sustainable practices, an important community belief because of the irreplaceable biological and cultural diversity of the region, if provided with economic assistance. Through understanding the perspectives of cafeteros and land management practices, conservation practitioners can integrate and improve ecological conservation practices with livelihoods.

Worldwide, land management has a dominant impact on conservation outcomes (Iverson et al. 2019, Hwang et al. 2020). Though shade coffee has been promoted as biodiversity friendly (Tscharntke et al. 2015, Solano et al. 2017), current coffee land management practices in the SNSM may be in conflict with amphibian conservation. Although amphibians do not directly use shade coffee in the SNSM, they use adjacent landscapes and waterbodies that are directly impacted by management practices (Roach et al. 2020). The lack of amphibians in coffee plantations is potentially because of the mismatch between land management practices that reduce or eliminate understory vegetation and leaf litter and alter soils (Robinson and Mansingh 1999, Rao et al. 2020). There is also more traffic by workers within coffee plantations during harvest so there may be less likelihood to find 
species as land use intensifies. In addition, coffee management practices intensify during an important life history period for amphibians, the reproductive (rainy) season (Fig. 4).

Practices such as application of fertilizers and herbicides and the clearing of understory growth may have detrimental impacts on amphibian reproductive and dispersal abilities. The clearing of understory vegetation eliminates important microhabitat reducing connectivity for amphibians (Earl and Semlitsch 2015), while the use of fertilizers may lead to disruptions in endocrinology and sexual differentiation (Boone et al. 2007, Mann et al. 2009). Amphibians that use watersheds adjacent to coffee plantations may be negatively impacted by management practices and subsequent changes in environmental conditions. The washing of coffee can impact streams through increases in heavy metal content, pesticides, and organic run-off (Arcila Pulgarín et al. 2007, Siu et al. 2007, Zayas Pérez et al. 2007), which increases acidity and depletes oxygen levels below acceptable levels in the water, negatively impacting environmental conditions in streams (Rattan et al. 2015, Dadi et al. 2018).

Given that cafeteros value water, there is a potential for a collaborative opportunity that prioritizes watershed conservation, protecting both amphibian habitat and an important resource for cafeteros. Water is used intensively during coffee processing (up to $140 \mathrm{~L}$ of water can be used to process one cup of coffee; Chapagain and Hoekstra 2003). First the fruit flesh is removed, with water, from the bean. The beans are then left to ferment in a water tank for 24-48 hours. Afterwards, the coffee beans are washed again. In the SNSM, water is filtered through a tank system, and the wastewater is disposed on land or in an adjacent stream. These same streams represent important riparian elements for amphibian habitat (Almeida et al. 2020, Roach et al. 2020). New and available technologies that reduce water consumption during coffee processing would help to greatly improve the sustainability of coffee production. Additionally, accountability and enforcement of laws is necessary to ensure that use of illegal fertilizers and wastewater contamination is reduced. Organic certifications prohibit the use of chemical fertilizers and pesticides, which is why some farmers choose not to be organic. As climates become more unpredictable, it can be difficult for cafeteros to produce bountiful harvests, which may impact decision making regarding land management, including certifications.

Globally, climate change has increased difficulties for coffee growers. Across Latin America, cafeteros are experiencing negative impacts on their coffee crop (Solano et al. 2017, Villarreal 2018, Andrade and Zapata 2019, Coltri et al. 2019). In the SNSM all five communities perceived the effects of climate change on the landscape and on their livelihoods (Rodríguez et al. 2021), as altered precipitation and temperature levels had damaged coffee fruits on their farms. Other regions in Colombia have also noted damage and reduction to crop yields due to climate change (Rodríguez et al. 2021). To adapt to new climatic conditions, cafeteros will need to shift management practices including planting drought and disease resistant hybrids and perhaps crop shifting. Other research suggests that coffee may need to move into new areas, which would increase deforestation in some regions (Schroth et al. 2015).

Ultimately, cafeteros are more likely to make land use decisions based on their economic well-being. At the time of this study, global coffee prices in Colombia were \$1.25 USD/LB (2017) and \$1.13 USD/LB (2018; International Coffee Organization 2021). Organic growers can sell coffee at slightly higher prices; however, the margin of increase is only viable if losses to pests, (e.g. from the coffee berry borer) are less than this and there is no significant loss of productivity because of reliance on organic fertilization. Economic limitations remain the largest barrier to the lack of implementation of sustainable technologies in the region. Like economic factors, infrastructure shortcomings also directly influence community decision making by increasing the costs of transportation and impact the environment through the ability of the communities to improve solid waste disposal. Cafeteros want economic support that will allow them to spend less of their own money on maintenance of their farms and machinery and to invest in organic programs. Both economic and infrastructure limitations may hinder the improvement of management practices to become more biodiversity friendly.

With economic support for cafeteros, conservation initiatives within agroforested matrices could achieve more progress and safeguard species habitat. It is important that community-level conservation and sustainable development projects take into consideration the role of livelihood decisions. Previous agroforestry research, in Nicaragua and El Salvador, demonstrated that well-managed shade coffee plantations can provide both livelihood and biodiversity benefits (Méndez et al. 2010). Key to their success, however, is careful integration of bottom-up community level initiatives coupled with top-down support providing necessary financial and human resources (Méndez et al. 2010).

Community support for conservation programs is critical to improve program implementation and accountability. Conflict arises when local people are left out of conservation decisions that take place on adjacent landscapes (Brockington and Wilkie 2015, Sodik et al. 2020). In regions where inequality and poverty are rampant, it can be difficult to gain community trust and build momentum for conservation action (Brooks et al. 2012), and there can be a disconnect between the perceived need of information and the technical support local land users actually receive (Barrucand et al. 2017). We recommend that conservation researchers who plan to implement a conservation program employ focus groups, a community workshop, or a similar approach to build community trust and engagement early on, which will help researchers better understand the complexities of the surrounding region and assist in addressing any design or implementation issues. The development of a graphical template through the qualitative content analysis demonstrates the relationships among main, generic, and subcategories (Fig. 3) and can be a framework for conservation planning. In our results, the two main categories were divergent on conservation program topics and livelihood issues. As we discuss, any conservation plan needs to address the interrelationships between these factors, as they influence each other. For example, environmental degradation in watersheds affects livelihoods, but the lack of stable income makes it nearly impossible for farmers to adopt more sustainable practices.

In summary, the results highlighted livelihood barriers for cafeteros that hinder consistent sustainable management of coffee farms and surrounding landscapes. Without addressing these barriers there will be little success enacting conservation plans 
across their landscapes. Perceptions of local land users are critical to understanding how decisions regarding future land use is made. Our two main themes derived from this study demonstrate that knowledge of local wildlife and climate, as well as socioeconomics and livelihoods, interact in the decision-making process and together necessarily contribute to coffee management decisions.

\section{SPECULATION}

Specifically, in the SNSM, in order to improve sustainability and equitable practices and bolster conservation efforts, we recommend three steps: (1) alleviate the economic strain on local cafeteros through social and economic government programs; (2) improve technology and coffee processing methods and their distribution to cafeteros; and (3) connect local cafeteros directly with buyers. Maintaining sustainable livelihoods will provide a mutual benefit for local ecosystems. Biodiversity conservation programs will be more effective when local land users have economic security that is based upon programs that respond to both local needs and perceptions. Interestingly, we found a link between cafeteros and amphibians and their value and dependence on water. Water could be the resource that links both livelihoods and biodiversity to achieve conservation goals in the region. In fact, the authors have begun preliminary work on the impacts of coffee processing on water quality. Conservation programs must further build upon the existing appreciation of the local environment and the pre-existing legacy of the land that communities find intrinsically meaningful to conserve.

Responses to this article can be read online at: https://www.ecologyandsociety.org/issues/responses. php/12449

\section{Acknowledgments:}

We would like to thank Dr. Edgar Ramirez, José Torras, Calet Vasquez, Luis Peña, Javier Mendoza, and Isabel Ruiz from the Federación Nacional de Cafeteros for all of their logistical support throughout the duration of this project. Thank you to Jose-Luis Pérez González for your assistance collecting data with focus groups. We would also like to thank all the coffee farmers from the five communities who participated in this research. Thank you to Dr. Mike Petriello and Dr. Christian Brannstrom, and the three anonymous reviewers for providing helpful insight to improve this manuscript. Finally, we thank our sources of funding for making this research possible including The Phoenix Zoo and the Fulbright US Scholars program.

\section{Data Availability:}

The data that support the findings of this study are available on request from the corresponding author, NSR. Our research was submitted to the Instructional Review Board and approved without requirement for a formal IRB due to the use of focal group data.

\section{LITERATURE CITED}

Agudelo-Hz, W. J., N. Urbina-Cardona, and D. ArmenterasPascual. 2019. Critical shifts on spatial traits and the risk of extinction of Andean anurans: an assessment of the combined effects of climate and land-use change in Colombia. Perspectives in Ecology and Conservation 17(4):206-219. https://doi. org/10.1016/j.pecon.2019.11.002

Almeida, P. C. de, M. T. Hartmann, and P. A. Hartmann. 2020. How riparian forest integrity influences anuran species composition: a case study in the Southern Brazil Atlantic Forest. Animal Biodiversity and Conservation 43(1):209-219. https://doi. org/10.32800/abc.2020.43.0209

Andrade, H. J., and P. C. Zapata. 2019. Mitigation of climate change of coffee production systems in Cundinamarca, Colombia. Floresta e Ambiente 26(3):e20180126. https://doi. org/10.1590/2179-8087.012618

Arcila Pulgarín, J., F. Farfán Valencia, A. M. Moreno Berrocal, L. F. Salzar Gutiérrez, and E. Hincapié Gómez. 2007. Sistemas de producción de café en Colombia. Cenicafé, Chinchiná, Colombia.

Avelino, J., M. Cristancho, S. Georgiou, P. Imbach, L. Aguilar, G. Bornemann, P. Läderach, F. Anzueto, A. J. Hruska, and C. Morales. 2015. The coffee rust crises in Colombia and Central America (2008-2013): impacts, plausible causes and proposed solutions. Food Security 7(2):303-321. https://doi.org/10.1007/ s12571-015-0446-9

Barrucand, M. G., C. Giraldo Vieira, and P. O. Canziani. 2017. Climate change and its impacts: perception and adaptation in rural areas of Manizales, Colombia. Climate and Development 9 (5):415-427. https://doi.org/10.1080/17565529.2016.1167661

Bennett, N. J. 2016. Using perceptions as evidence to improve conservation and environmental management. Conservation Biology 30(3):582-592. https://doi.org/10.1111/cobi.12681

Bennett, N. J., R. Roth, S. C. Klain, K. Chan, P. Christie, D. A. Clark, G. Cullman, D. Curran, T. J. Durbin, G. Epstein, A. Greenberg, M. P. Nelson, J. Sandlos, R. Stedman, T. L. Teel, R. Thomas, D. Veríssimo, and C. Wyborn. 2017. Conservation social science: understanding and integrating human dimensions to improve conservation. Biological Conservation 205:93-108. https://doi.org/10.1016/j.biocon.2016.10.006

Bernal, M. H., and J. D. Lynch. 2008. Review and analysis of altitudinal distribution of the Andean anurans in Colombia. Zootaxa 1826:1-25. https://doi.org/10.11646/zootaxa.1826.1.1

Bernard, H. R. 2006. Research methods in anthropology: qualitative and quantitative approaches. Fourth edition. AltaMira Press, Lanham, Maryland, USA.

Boone, M. D., R. D. Semlitsch, E. E. Little, and M. C. Doyle. 2007. Multiple stressors in amphibian communities: effects of chemical contamination, bullfrogs, and fish. Ecological Applications 17(1):291-301. https://doi.org/10.1890/1051-0761 (2007)017[0291:MSIACE]2.0.CO;2

Brockington, D., and D. Wilkie. 2015. Protected areas and poverty. Philosophical Transactions of the Royal Society B: Biological Sciences 370(1681):20140271. https://doi.org/10.1098/ $\underline{\text { rstb.2014.0271 }}$

Brook, R., and S. McLachlan. 2008. Trends and prospects for local knowledge in ecological and conservation research and monitoring. Biodiversity and Conservation 17:3501-3512. https:// doi.org/10.1007/s10531-008-9445-x 
Brooks, J. S., K. A. Waylen, and M. Borgerhoff Mulder. 2012. How national context, project design, and local community characteristics influence success in community-based conservation projects. Proceedings of the National Academy of Sciences 109 (52):21265-21270. https://doi.org/10.1073/pnas.1207141110

Caudill, S. A., and R. A. Rice. 2016. Do bird friendly ${ }^{\circledR}$ coffee criteria benefit mammals? Assessment of mammal diversity in Chiapas, Mexico. PLOS ONE 11(11):e0165662. https://doi. org/10.1371/journal.pone.0165662

Chambers, R., and G. Conway. 1992. Sustainable rural livelihoods: practical concepts for the 21st century. IDS University of Sussex, Brighton, UK.

Chapagain, A. K., and A. Y. Hoekstra. 2003. The water needed to have the Dutch drink coffee. UNESCO-IHE Institute for Water Education, Delft, The Netherlands.

Cho, J. Y., and E-H. Lee. 2014. Reducing confusion about grounded theory and qualitative content analysis: similarities and differences. Qualitative Report 19(32):1-20. https://doi. org/10.46743/2160-3715/2014.1028

Coltri, P. P., H. S. Pinto, R. R. do V. Gonçalves, J. Zullo Junior, and V. Dubreuil. 2019. Low levels of shade and climate change adaptation of Arabica coffee in southeastern Brazil. Heliyon 5(2): e01263. https://doi.org/10.1016/j.heliyon.2019.e01263

Comite de Cafeteros Magdalena. 2021. Café del Magdalena. Federación Nacional de Cafeteros Santa Marta, Colombia. [online] URL: https://magdalena.federaciondecafeteros.org/cafedel-magdalena/

Dadi, D., E. Mengistie, G. Terefe, T. Getahun, A. Haddis, W. Birke, A. Beyene, P. Luis, and B. Van der Bruggen. 2018. Assessment of the effluent quality of wet coffee processing wastewater and its influence on downstream water quality. Ecohydrology \& Hydrobiology 18(2):201-211. https://doi. org/10.1016/j.ecohyd.2017.10.007

Damon, A. 2000. A review of the biology and control of the coffee berry borer, Hypothenemus hampei (Coleoptera: Scolytidae). Bulletin of Entomological Research 90(6):453-465. https://doi. org/10.1017/S0007485300000584

Earl, J. E., and R. D. Semlitsch. 2015. Importance of forestry practices relative to microhabitat and microclimate changes for juvenile pond-breeding amphibians. Forest Ecology and Management 357:151-160. https://doi.org/10.1016/j.foreco.2015.08.023

Elo, S., and H. Kyngäs. 2008. The qualitative content analysis process. Journal of Advanced Nursing 62(1):107-115. https://doi. org/10.1111/j.1365-2648.2007.04569.X

Etter, A., C. McAlpine, K. Wilson, S. Phinn, and H. Possingham. 2006. Regional patterns of agricultural land use and deforestation in Colombia. Agriculture, Ecosystems \& Environment 114 (2-4):369-386. https://doi.org/10.1016/j.agee.2005.11.013

Farfán Valencia, F. 2014. Agroforestería y sistemas agroforestales con café. Cenicafé, Federación de Cafeteros, Manizales, Colombia.

Federación Nacional de Cafeteros. 2009. Comité Departamental de Cafeteros de Magdalena. Informe Comités Departamentales, Federación Nacional de Cafeteros, Santa Marta, Colombia.
Federación Nacional de Cafeteros. 2015. Informe de Sostenibilidad 2015 - 2018. Informe de Sostenibilidad, Federación Nacional de Cafeteros, Santa Marta, Colombia.

Flechas, S. V., A. Paz, A. J. Crawford, C. Sarmiento, A. A. Acevedo, A. Arboleda, W. Bolívar-García, C. L. EcheverrySandoval, R. Franco, C. Mojica, A. Muñoz, P. PalaciosRodríguez, A. M. Posso-Terranova, P. Quintero-Marín, L. A. Rueda-Solano, F. Castro-Herrera, and A. Amézquita. 2017. Current and predicted distribution of the pathogenic fungus Batrachochytrium dendrobatidis in Colombia, a hotspot of amphibian biodiversity. Biotropica 49(5):685-694. https://doi. org/10.1111/btp. 12457

Gallmetzer, N., and C. H. Schulze. 2015. Impact of oil palm agriculture on understory amphibians and reptiles: a Mesoamerican perspective. Global Ecology and Conservation 4:95-109. https://doi.org/10.1016/j.gecco.2015.05.008

González, A. M., S. Wilson, N. J. Bayly, and K. A. Hobson. 2020. Contrasting the suitability of shade coffee agriculture and native forest as overwinter habitat for Canada Warbler (Cardellina canadensis) in the Colombian Andes. Condor 122(2):duaa011. https://doi.org/10.1093/condor/duaa011

Granados-Peña, R., A. Arias-Alzate, D. Zárrate-Charry, and J. F. González-Maya. 2014. Una estrategia de conservación a escala regional para el jaguar (Panthera onca) en el distrito biogeográfico de la Sierra Nevada de Santa Marta, Colombia. Revista Biodiversidad Neotropical 4(2):141-148.

Guzmán, A., A. Link, J. A. Castillo, and J. E. Botero. 2016. Agroecosystems and primate conservation: shade coffee as potential habitat for the conservation of Andean night monkeys in the northern Andes. Agriculture, Ecosystems \& Environment 215:57-67. https://doi.org/10.1016/j.agee.2015.09.002

Haggar, J., M. Barrios, M. Bolaños, M. Merlo, P. Moraga, R. Munguia, A. Ponce, S. Romero, G. Soto, C. Staver, and E. de M. F. Virginio. 2011. Coffee agroecosystem performance under full sun, shade, conventional and organic management regimes in Central America. Agroforestry Systems 82(3):285-301. https:// doi.org/10.1007/s10457-011-9392-5

Hannah, L., C. I. Donatti, C. A. Harvey, E. Alfaro, D. A. Rodriguez, C. Bouroncle, E. Castellanos, F. Diaz, E. Fung, H. G. Hidalgo, P. Imbach, P. Läderach, J. P. Landrum, and A. L. Solano. 2017. Regional modeling of climate change impacts on smallholder agriculture and ecosystems in Central America. Climatic Change 141(1):29-45. https://doi.org/10.1007/s10584-016-1867$\mathrm{y}$

Herzog, S. K., R. Martínez, P. Jørgensen, and H. Tiessen, editors. 2011. Climate change and biodiversity in the tropical Andes. InterAmerican Institute for Global Change Research (IAI), Montevideo Uruguay, and Scientific Committee on Problems of the Environment (SCOPE), Amstelveen, The Netherlands.

Hoyos-Hoyos, J. M., P. Isaacs-Cubides, N. Devia, D. M. GalindoUribe, and A. R. Acosta-Galvis. 2012. An approach to the ecology of the herpetofauna in agroecosystems of the Colombian coffee zone. South American Journal of Herpetology 7(1):25-34. https:// doi.org/10.2994/057.007.0103 
Hsieh, H.-F., and S. E. Shannon. 2005. Three approaches to qualitative content analysis. Qualitative Health Research 15 (9):1277-1288. https://doi.org/10.1177/1049732305276687

Hudson, L., T. Newbold, S. Contu, S. Hill, and I. Lysenko, A. De Palma, H. R. A. Senior, D. J. Bennett, H. Booth, et al. 2014. The PREDICTS database: a global database of how local terrestrial biodiversity responds to human impacts. Ecology and Evolution 4:4701-4735. https://doi.org/10.1002/ece3.1303

Hwang, B., K. Hundera, B. Mekuria, A. Wood, and A. Asfaw. 2020. Intensified management of coffee forest in southwest Ethiopia detected by Landsat imagery. Forests 11(4(:422). https:// doi.org/10.3390/f11040422

International Coffee Organization. 2018. Coffee market report. International Coffee Organization, London, UK.

International Coffee Organization. 2020. Monthly export statistics (members \& non-members). International Coffee Organization, London, UK.

International Coffee Organization. 2021. Prices paid to growers in exporting countries. International Coffee Organization, London, UK. [online] URL: https://www.ico.org/historical/1990\% 20onwards/PDF/3a-prices-growers.pdf

Iverson, A. L., D. J. Gonthier, D. Pak, K. K. Ennis, R. J. Burnham, I. Perfecto, M. Ramos Rodriguez, and J. H. Vandermeer. 2019. A multifunctional approach for achieving simultaneous biodiversity conservation and farmer livelihood in coffee agroecosystems. Biological Conservation 238:108179. https://doi.org/10.1016/j. biocon.2019.07.024

Joa, B., G. Winkel, and E. Primmer. 2018. The unknown known - a review of local ecological knowledge in relation to forest biodiversity conservation. Land Use Policy 79:520-530. https:// doi.org/10.1016/j.landusepol.2018.09.001

Krippendorff, K. 1980. Content analysis: an introduction to its methodology. SAGE, Newbury Park, California, USA.

Krueger, R., and M. Casey. 2000. Focus groups: a practical guide for applied researchers. Third edition. SAGE, Thousand Oaks, California, USA.

Läderach, P., J. Ramirez-Villegas, C. Navarro-Racines, C. Zelaya, A. Martinez-Valle, and A. Jarvis. 2017. Climate change adaptation of coffee production in space and time. Climatic Change 141(1):47-62. https://doi.org/10.1007/s10584-016-1788-9

Le Saout, S., M. Hoffmann, Y. Shi, A. Hughes, C. Bernard, T. M. Brooks, B. Bertzky, S. H. M. Butchart, S. N. Stuart, T. Badman, and A. S. L. Rodrigues. 2013. Protected areas and effective biodiversity conservation. Science 342:803-805. https://doi. org/10.1126/science. 1239268

Leclère, D., M. Obersteiner, M. Barrett, S. H. M. Butchart, A. Chaudhary, A. De Palma, F. A. J. DeClerck, M. Di Marco, J. C. Doelman, M. Dürauer, et al. 2020. Bending the curve of terrestrial biodiversity needs an integrated strategy. Nature 585:551-556. https://doi.org/10.1038/s41586-020-2705-y

Lowder, S. K., J. Skoet, and T. Raney. 2016. The number, size, and distribution of farms, smallholder farms, and family farms worldwide. World Development 87:16-29. https://doi.org/10.1016/ j.worlddev.2015.10.041
Mann, R. M., R. V. Hyne, C. B. Choung, and S. P. Wilson. 2009. Amphibians and agricultural chemicals: review of the risks in a complex environment. Environmental Pollution 157(11):2903-2927. https://doi.org/10.1016/j.envpol.2009.05.015

McCain, C. M., and R. K. Colwell. 2011. Assessing the threat to montane biodiversity from discordant shifts in temperature and precipitation in a changing climate. Ecology Letters 14 (12):1236-1245. https://doi.org/10.1111/j.1461-0248.2011.01695. $\underline{x}$

Méndez, V. E., C. M. Bacon, M. Olson, K. S. Morris, and A. Shattuck. 2010. Agrobiodiversity and shade coffee smallholder livelihoods: a review and synthesis of ten years of research in Central America. Professional Geographer 62(3):357-376. https:// doi.org/10.1080/00330124.2010.483638

Menéndez-Guerrero, P. A., D. M. Green, and T. J. Davies. 2020. Climate change and the future restructuring of Neotropical anuran biodiversity. Ecography 43(2):222-235. https://doi. org/10.1111/ecog.04510

Montgomery, M. 2019. Adaptation under the canopy: coffee cooperative and certification contributions to smallholder livelihood sustainability in Santa Lucía Teotepec, Oaxaca. Thesis. University of Montana, Missoula, Montana, USA.

Múnera, C., and L. van Kerkhoff. 2019. Diversifying knowledge governance for climate adaptation in protected areas in Colombia. Environmental Science \& Policy 94:39-48. https://doi. org/10.1016/j.envsci.2019.01.004

Murrieta-Galindo, R., A. González-Romero, F. López-Barrera, and G. Parra-Olea. 2013. Coffee agrosystems: an important refuge for amphibians in central Veracruz, Mexico. Agroforestry Systems 87(4):767-779. https://doi.org/10.1007/s10457-013-9595$\underline{Z}$

Mwenge Kahinda, J., P. Bahal'okwibale, N. Budaza, S. Mavundla, N. Nohayi, K. Nortje, and R. Boroto. 2019. Compendium of community and indigenous strategies for climate change adaptation - focus on addressing water scarcity in agriculture. Food and Agriculture Organization, Rome, Italy.

Myers, N., R. A. Mittermeier, C. G. Mittermeier, G. A. B. da Fonseca, and J. Kent. 2000. Biodiversity hotspots for conservation priorities. Nature 403(6772):853-858. https://doi.org/10.1038/35002501

Nagayets, O. 2005. Small farms: current status and key trends. Pages 26-29 in The future of small farms: Proceedings of a research workshop, Wye, UK, June. International Food Policy Research Institute, Washington, D.C., USA.

Narango, D. L., D. W. Tallamy, K. J. Snyder, and R. A. Rice. 2019. Canopy tree preference by insectivorous birds in shade-coffee farms: implications for migratory bird conservation. Biotropica 51(3):387-398. https://doi.org/10.1111/btp.12642

Nowakowski, A. J., L. O. Frishkoff, M. E. Thompson, T. M. Smith, and B. D. Todd. 2018. Phylogenetic homogenization of amphibian assemblages in human-altered habitats across the globe. Proceedings of the National Academy of Sciences 115(15): E3454-E3462. https://doi.org/10.1073/pnas.1714891115

Ocampo-Peñuela, N., and S. L. Pimm. 2014. Setting practical conservation priorities for birds in the western Andes of 
Colombia. Conservation Biology 28(5):1260-1270. https://doi. org/10.1111/cobi.12312

Onwuegbuzie, A. J., W. B. Dickinson, N. L. Leech, and A. G. Zoran. 2009. A qualitative framework for collecting and analyzing data in focus group research. International Journal of Qualitative Methods 8(3):1-21. https://doi.org/10.1177/1609406$\underline{90900800301}$

Otero-Jiménez, B., J. H. Vandermeer, and P. K. Tucker. 2018. Effect of coffee agriculture management on the population structure of a forest dwelling rodent (Heteromys desmarestianus goldmani). Conservation Genetics 19(2):495-499. https://doi. org/10.1007/s10592-017-1016-9

Patton, M. 2002. Qualitative research and evaluation methods. SAGE, London, UK.

Perfecto, I., M. E. Jiménez-Soto, and J. Vandermeer. 2019. Coffee landscapes shaping the Anthropocene: forced simplification on a complex agroecological landscape. Current Anthropology 60(20): S236-S250. https://doi.org/10.1086/703413

Perfecto, I., and J. Vandermeer. 2008. Biodiversity conservation in tropical agroecosystems. Annals of the New York Academy of Sciences 1134(1):173-200. https://doi.org/10.1196/annals.1439.011

Perfecto, I., and J. Vandermeer. 2010. The agroecological matrix as alternative to the land-sparing/agriculture intensification model. Proceedings of the National Academy of Sciences 107 (13):5786-5791. https://doi.org/10.1073/pnas.0905455107

Philpott, S. M., W. J. Arendt, I. Armbrecht, P. Bichier, T. V. Diestch, C. Gordon, R. Greenberg, I. Perfecto, R. ReynosoSantos, L. Soto-Pinto, C. Tejeda-Cruz, G. Williams-Linera, J. Valenzuela, and J. M. Zolotoff. 2008. Biodiversity loss in Latin American coffee landscapes: review of the evidence on ants, birds, and trees. Conservation Biology 22(5):1093-1105. https://doi. org/10.1111/j.1523-1739.2008.01029.X

Ramirez-Villegas, J., M. Salazar, A. Jarvis, and C. E. NavarroRacines. 2012. A way forward on adaptation to climate change in Colombian agriculture: perspectives towards 2050. Climatic Change 115(3-4):611-628. https://doi.org/10.1007/s10584-012-0500y

Rao, M. V., R. A. Rice, R. C. Fleischer, and C. R. Muletz-Wolz. 2020. Soil fungal communities differ between shaded and sunintensive coffee plantations in El Salvador. PLoS ONE 15(4): e0231875. https://doi.org/10.1371/journal.pone.0231875

Rattan, S., A. K. Parande, V. D. Nagaraju, and G. K. Ghiwari. 2015. A comprehensive review on utilization of wastewater from coffee processing. Environmental Science and Pollution Research 22(9):6461-6472. https://doi.org/10.1007/s11356-015-4079-5

Roach, N. S., N. Urbina-Cardona, and T. E. Lacher Jr. 2020. Land cover drives amphibian diversity across steep elevational gradients in an isolated neotropical mountain range: implications for community conservation. Global Ecology and Conservation 22:e00968. https://doi.org/10.1016/j.gecco.2020.e00968

Robinson, D. E., and A. Mansingh. 1999. Insecticide contamination of Jamaican environment. IV. Transport of residues from coffee plantations in the Blue Mountains to coastal waters in eastern Jamaica. Environmental Monitoring and Assessment 54:125-141. https://doi.org/10.1023/A:1005806815959

Rodríguez, J. de J. N., J. C. C. Rodríguez, D. M. Carrero, L. L. R. Novoa, and J. V. S. Frank. 2021. Representations of Colombian Andean farmers on climate change and mitigation and adaptation strategies. Revista de Economia e Sociologia Rural 59:2. https:// doi.org/10.1590/1806-9479.2021.220439

Sawchuk, J. H., A. H. Beaudreau, D. Tonnes, and D. Fluharty. 2015. Using stakeholder engagement to inform endangered species management and improve conservation. Marine Policy 54:98-107. https://doi.org/10.1016/j.marpol.2014.12.014

Schreier, M. 2012. Qualitative content analysis in practice. SAGE, Los Angeles, California, USA.

Schroth, G., P. Läderach, D. S. Blackburn Cuero, J. Neilson, and C. Bunn. 2015. Winner or loser of climate change? A modeling study of current and future climatic suitability of Arabica coffee in Indonesia. Regional Environmental Change 15(7):1473-1482. https://doi.org/10.1007/s10113-014-0713-x

Siu, Y., G. Mejia, J. Mejia-Saavedra, J. Pohlan, and M. Sokolov. 2007. Heavy metals in wet method coffee processing wastewater in Soconusco, Chiapas, Mexico. Bulletin of Environmental Contamination and Toxicology 78(5):400-404. https://doi. org/10.1007/s00128-007-9094-X

Sodik, M., S. Pudyatmoko, P. S. H. Yuwono, and M. A. Imron. 2020. Forest conflict mitigation through coffee-based agroforestry provide secure habitat for Javan Slow Lorise in a lowland fragmented forest in Central Java, Indonesia. IOP Conference Series: Earth and Environmental Science 449:012050. https://doi.org/10.1088/1755-1315/449/1/012050

Solano, A. L., D. Pons, C. Tucker, R. Díaz, J. Barrera, H. Eakin, and E. Castellanos. 2017. Biodiversity, sustainable certifications and climate change adaptation: lessons from shade coffee systems in Mesoamerica. Pages 133-138 in Symposium on Biodiversity and Climate Change, Contributions from Science to Policy, Lima, Peru. Center on Biological Diversity.

Stewart, D., P. Shamdasani, and D. Rook. 2009. Group depth interviews: focus group research. Pages 589-616 in L. Bickman and D. J. Rog, editors. The SAGE handbook of applied social research methods. SAGE, Thousand Oaks, California, USA. https://doi.org/10.4135/9781483348858.n18

Thornton, T. F., and A. Maciejewski Scheer. 2012. Collaborative engagement of local and traditional knowledge and science in marine environments: a review. Ecology and Society 17(3):8. https://doi.org/10.5751/ES-04714-170308

Tscharntke, T., J. C. Milder, G. Schroth, Y. Clough, F. DeClerck, A. Waldron, R. Rice, and J. Ghazoul. 2015. Conserving biodiversity through certification of tropical agroforestry crops at local and landscape scales. Conservation Letters 8(1):14-23. https://doi.org/10.1111/conl.12110

Villarreal, A. 2018. Peasant coffee farmers and climate change: the case of café justo in Chiapas, Mexico. Thesis. Arizona State University, Tempe, Arizona, USA. 
Wilkinson, S. 2004. Focus group research. Pages 177-199 in D. Silverman, editor. Qualitative research: theory, method, and practice. SAGE, Thousand Oaks, California, USA.

Zayas Pérez, T., G. Geissler, and F. Hernandez. 2007. Chemical oxygen demand reduction in coffee wastewater through chemical flocculation and advanced oxidation processes. Journal of Environmental Sciences 19(3):300-305. https://doi.org/10.1016/ s1001-0742(07)60049-7

Zimmerer, K. S. 2002. Common field agriculture as a cultural landscape of Latin America: development and history in the geographical customs of resource use. Journal of Cultural Geography 19(2):37-63. https://doi.org/10.1080/08873630209478288 
Appendix 1: Focal Groups questions which we used to guide discussions. We allowed for freedom of discussion to flow throughout focal group interviews depending on the groups interest of information of particularly topics. Documented in both English and Spanish.

Table A1.1. Focal Group discussion questions, Part 1

\begin{tabular}{|c|c|c|}
\hline Biodiversity & Sustainability & Governance \\
\hline $\begin{array}{l}\text { What types of animals do you see on your } \\
\text { farm? ¿Qué tipo de animales has visto en } \\
\text { su tierra? ¿En qué partes las ve? }\end{array}$ & $\begin{array}{l}\text { What do you do with the water and fruit after } \\
\text { the coffee is processed? ¿Qué hacen con el } \\
\text { agua y los frutos del café después de que el } \\
\text { café es procesando? }\end{array}$ & $\begin{array}{l}\text { What's your relationship with FNC? ¿Cuál es } \\
\text { su relación con Federación de Cafeteros? }\end{array}$ \\
\hline $\begin{array}{l}\text { Do you have frogs on your land? Did you use } \\
\text { to have frogs? If so where were/are they? } \\
\text { ¿Hay ranas en tu tierra? ¿Había ranas antes? } \\
\text { ¿Si las había dónde estaban? What types of } \\
\text { animals do you see on your farm? ¿Qué tipo } \\
\text { de animales has visto en su tierra? ¿En qué } \\
\text { partes las ve? }\end{array}$ & $\begin{array}{l}\text { Do you have certifications? What type of } \\
\text { certifications do you have? Why did you } \\
\text { choose this certification? Why do you choose } \\
\text { no certification? Do you want to be certified? } \\
\text { ¿Tiene certificados? ¿Que tipos de } \\
\text { certificados tienes? ¿Porque eligió esa } \\
\text { certificación? ¿Porque no eligío un sistema } \\
\text { de certificados? Quieres obtener alguno(s) } \\
\text { tipos de certificados? }\end{array}$ & $\begin{array}{l}\text { Does the Colombian government support } \\
\text { coffee farmers? Do you think this could be } \\
\text { improved? How could this be } \\
\text { improved? How could that be better for you? } \\
\text { What would this help you do that you cannot } \\
\text { do now? Piensas que el gobierno de } \\
\text { Colombia apoya a los cafeteros? Piensas } \\
\text { que esto podría mejorar? ¿Cómo podría ser } \\
\text { mejorado? ¿Cómo sería mejor para ti? } \\
\text { ¿Cómo te ayudaría esto a hacer algo que no } \\
\text { puedes hacer ahora? }\end{array}$ \\
\hline $\begin{array}{l}\text { Are you familiar with the term biodiversity? If } \\
\text { yes: What is the definition? ¿Estas } \\
\text { familiarizado con la palabra biodiversidad? Si } \\
\text { la conoces, ¿podrías explicarme cuál es su } \\
\text { definición? }\end{array}$ & $\begin{array}{l}\text { Would you be willing to engage in a program } \\
\text { where you donated your coffee fruit/ casks to } \\
\text { reduce waste? (if you were paid?) ¿Podrías } \\
\text { participar en un programa donde se donará } \\
\text { las cascaras del café y elimina los frutos } \\
\text { rojos? ¿Si te pagaran? }\end{array}$ & \\
\hline \multicolumn{3}{|l|}{$\begin{array}{l}\text { What do you think about biodiversity? } \\
\text { ¿Que piensas que es la biodiversidad? }\end{array}$} \\
\hline $\begin{array}{l}\text { Do you accommodate biodiversity on your } \\
\text { land? How? (For example maintain areas that } \\
\text { are forested) Ud. hace algo para mantener } \\
\text { animales en su tierra? Por ejemplo, ¿mantener } \\
\text { áreas forestadas? }\end{array}$ & & \\
\hline
\end{tabular}


Table A1.2. Focal Group discussion questions, Part 2.

\begin{tabular}{|c|c|c|}
\hline Climate Change & Values & Background/History \\
\hline $\begin{array}{l}\text { Have you observed changes in the weather or } \\
\text { climate? (If yes) Which changes have you } \\
\text { notices? When did you observe these } \\
\text { changes? Have these changes impacted you? } \\
\text { In which way (productivity of coffee or your } \\
\text { life)? ¿Has observado cambios en el clima? Si } \\
\text { los has observado, ¿qué tipo de cambios has } \\
\text { observado? ¿Cuándo observaste estos } \\
\text { cambios? ¿Estos cambios tuvieron algún } \\
\text { impacto en ti? ¿De qué manera? } \\
\text { (¿productividad de café, otro tipo de } \\
\text { agricultura, o su vida?) }\end{array}$ & $\begin{array}{l}\text { What is the most important thing to you about } \\
\text { 1) your land, 2) the SNSM? ¿Qué es lo } \\
\text { más importantes de la 1) su tierra, 2) la } \\
\text { sierra? }\end{array}$ & $\begin{array}{l}\text { How long have you been farming coffee? Did } \\
\text { you grow up farming coffee? Did your } \\
\text { parents farm coffee? Do you own the land on } \\
\text { which you grow coffee? If yes, for how } \\
\text { long? ¿Creciste cosechando café? ¿Tus } \\
\text { padres sembraban café? ¿Eres el dueño de } \\
\text { la tierra dónde cosechas el café? ¿Si eres el } \\
\text { dueño, desde hace cuándo posees la tierra? } \\
\text { For those not owner of the land: ¿O cuál es } \\
\text { su título? ¿Hace cuánto trabajas en esa finca } \\
\text { o en la Sierra? }\end{array}$ \\
\hline $\begin{array}{l}\text { Do you have any concerns about the future of } \\
\text { coffee in this region? Tienes alguna } \\
\text { preocupación sobre el futuro del café en esta }\end{array}$ & $\begin{array}{l}\text { What do you think about the future of coffee in } \\
\text { the SNSM? ¿Que piensas del futuro del café } \\
\text { en la sierra? }\end{array}$ & $\begin{array}{l}\text { What other crops do you grow? ¿Cual son } \\
\text { los otros tipos de agricultura que tienen? }\end{array}$ \\
\hline $\begin{array}{l}\text { What would you do if you could not grow coffee } \\
\text { in the same place you grow it now? Do you } \\
\text { have any other options? (i.e. other crops or } \\
\text { moving - I wanted to see if they have any } \\
\text { adaptive capacity). ¿Qué harías si no puedes } \\
\text { cosechar más café en el mismo lugar en el que } \\
\text { lo haces ahora? Tienes alguna otra opción? } \\
\text { (¿por ejemplo, otras cosechar o moverse de } \\
\text { lugar? ¿Si no puedes cosechar café en el } \\
\text { mismo sector o lugar, qué harías? ¿Por } \\
\text { ejemplo, tiene opciones de otros tipos de } \\
\text { cultivos? ¿O puedes mover sus plantas de } \\
\text { café a otro lugar? }\end{array}$ & $\begin{array}{l}\text { Who will continue to work on the farms? } \\
\text { (many young people aren't interested, tried } \\
\text { not to ask this without guiding the question } \\
\text { somewhere). ¿Quién va a continuar } \\
\text { trabajando en las fincas ya que ahora los } \\
\text { jóvenes no muestran mucho interés en } \\
\text { continuar cosechando? }\end{array}$ & $\begin{array}{l}\text { What are the best and worst prices you've } \\
\text { received for coffee? Is there an average } \\
\text { price? ¿Cual son los mejores y peores } \\
\text { pagos que reciben por su café? ¿Los } \\
\text { precios son estables o cambia mucho? } \\
\text { ¿Hay un precio promedio? } \\
\\
\text { What is your main source of income? } \\
\text { ¿Cuál es su metódo principal de } \\
\text { ingresos? }\end{array}$ \\
\hline
\end{tabular}


Appendix 2: Summary of focal group talking points and emphases in each subcategory across all five focus groups - Palmor, Plan de Las Ollas, San Javier, San Pedro, and Vista Nieve. Moderator observations from focus groups are included below in the final row.

Table A2.1 The community of Palmor $(n=16)$ presented here.

\begin{tabular}{ll}
\hline \hline Subcategories & Palmor \\
\hline Biodiversity \& Wildlife & Farms, pastures, forest, trees, animals - the variety of everything. Birds: toucans, macaws, turkey hen; \\
& mammals (pigs and deer; pumas eat armadillos) and frogs, reptiles (snakes). \\
Climate Change & More water 10 years ago. Need to move higher to be cooler. Previously, cool at 1200 - 1250 m now it is \\
& $1700-2000 \mathrm{~m}$. Storms are more intense - all water falls in one week; rains are less common but \\
& stronger. Mules tire frequently. \\
Value of Land & Water. Coffee production. The sierra has everything (expressed gratitude). \\
Coffee Certifications & Organics do not contaminate water, very strict rules (no chemicals, fumigation, burning), Inspectors visit \\
& homes and coffee plantations (enforce that no one under 18 works), difficult to obtain organic \\
& certification. Farmers make their own decisions, independent of certifications "if want to have a good \\
farm you shouldn't use chemicals". Complaints about low market prices.
\end{tabular}


Table A2.2 The community of Plan de las Ollas $(n=7)$ presented here.

\begin{tabular}{|c|c|}
\hline Subcategories & Plan de las Ollas \\
\hline Biodiversity \& Wildlife & $\begin{array}{l}\text { Biodiversity: everything in land/environment. Wildlife: Mammals (armadillos, monkeys, tigrillo eats } \\
\text { armadillos), reptiles (snakes), birds (Crested oropendola), amphibians (Boana boans or rana } \\
\text { plantanero). Farmers do not hunt wildlife. Avoid fumigating. }\end{array}$ \\
\hline Climate Change & $\begin{array}{l}\text { Temperatures have increased, precipitation levels have changed. There used to be snow in June in the } \\
\text { peaks. } 25-30 \text { years ago it was another climate. Climate change affects their crops because they can't } \\
\text { plant coffee. }\end{array}$ \\
\hline Value of Land & Land: water, coffee, agriculture, and their home. Sierra: it's unique. \\
\hline Coffee Certifications & $\begin{array}{l}\text { Coffee certifications: Red Ecolsierra. Farmers join cooperatives because they provide income (higher } \\
\text { prices and better markets) and assistance. }\end{array}$ \\
\hline Socio-economic limitations & $\begin{array}{l}\text { Low coffee prices. Sons leave for cities, over time they may sell their lands. Want alternative crops to } \\
\text { coffee and also interested in ecotourism. Want to derive new economic strategies like incentives for } \\
\text { farmers that participate in conservation programs. }\end{array}$ \\
\hline Infrastructure & Improve roads. \\
\hline $\begin{array}{l}\text { Moderator observations from } \\
\text { focal groups discussions }\end{array}$ & $\begin{array}{l}\text { Farmers were happy to have the meeting stating its importance to learn about biodiversity and } \\
\text { conservation. The farmers had lots of knowledge about animal behavior in birds and mammals. }\end{array}$ \\
\hline
\end{tabular}


Table A2.3 The community of San Javier $(n=7)$ presented here.

\begin{tabular}{|c|c|}
\hline Subcategories & San Javier \\
\hline Biodiversity \& Wildlife & $\begin{array}{l}\text { Biodiversity is the ecosystem; species of flora and fauna. Wildlife: mammals (Agoutis, monkeys, deer, } \\
\text { squirrel, guartinaja (lowland paca), jaguar, armadillos, foxes), birds (turkey hen), amphibians (frogs and } \\
\text { toads) }\end{array}$ \\
\hline Climate Change & $\begin{array}{l}\text { Changes in precipitation and length of dry season (shorter). Coffee fruits cannot grow fully and fruits fall } \\
\text { off early. }\end{array}$ \\
\hline Value of Land & Small watersheds and taking care of the ecosystem, Sierra is important. \\
\hline Coffee Certifications & $\begin{array}{l}\text { Collective certificates ensure that the purchased coffee is high quality and organic. The minimum price is } \\
15 \text { thousand COP/kilogram ( } \sim 5 \mathrm{USD} / 2.2 \mathrm{lbs}) \text {. Organic requirements include no chemicals and no } \\
\text { burning, government provides money (prima organica) which lasts past cosecha. }\end{array}$ \\
\hline Socio-economic limitations & $\begin{array}{l}\text { History of conflict and land displacement, many people were killed or left but eventually came back when } \\
\text { it was safe. Farmers want higher coffee prices. Current coffee prices are so low that the money farmers } \\
\text { gain doesn't outweigh the money farmers spend on processing their coffee. Thank FNC for regulating } \\
\text { prices. }\end{array}$ \\
\hline Infrastructure & Better access, previously kids would walk $4-5$ hours a day to get to school. \\
\hline $\begin{array}{l}\text { Moderator observations from } \\
\text { focal groups discussions }\end{array}$ & $\begin{array}{l}\text { La junta de acción comunal (community leadership, elected by the community that oversees } \\
\text { communities needs and mediate between government entities), forbids people who own forest from } \\
\text { hunting. Participants do a clean-up with kids every other day to teach the importance of landscape and } \\
\text { sense of belonging. FNC gives security to farmers through guarantees of coffee purchases. Topics } \\
\text { differed by age of participants: older were more interested in discussing history of conflict and coffee } \\
\text { while the younger were more interested in biodiversity, clean water and air. }\end{array}$ \\
\hline
\end{tabular}


Table A2.4 The community of San Pedro $(n=10)$ presented here.

\begin{tabular}{|c|c|}
\hline Subcategories & San Pedro \\
\hline Biodiversity \& Wildlife & $\begin{array}{l}\text { Biodiversity: plants, animals, and weather. Wildlife: mammals (deer, jaguar, oncilla); birds (black-chested } \\
\text { jay, turkey hen, toucans eat coffee); reptiles (they kill venomous snakes but not others like boas), } \\
\text { amphibians (listen to frogs \& toads). }\end{array}$ \\
\hline Climate Change & $\begin{array}{l}\text { Coffee, plants, and animal ranges have shifted to higher elevations. Warmer temperatures and water. } \\
\text { Farmers have had to change crops to cultivate avocado \& mango; } 90 \% \text { of seeds are roya (coffee rust) } \\
\text { resistant. }\end{array}$ \\
\hline Value of Land & Conservation of the land and improve productivity of coffee landscapes. \\
\hline Coffee Certifications & $\begin{array}{l}\text { Most farmers have organic certifications/associations. Different associations have different rules. Can } \\
\text { take up to three years of preparation to become organic. There are internal and external inspections. } \\
\text { Red Ecolsierra does two visits/year, one in March and one in August, and also exports coffee. Organic } \\
\text { associations receive better prices for the coffee, and a social bonus (prima social) to do improvements } \\
\text { on their farms. Government gives coffee farmers credits in the bank but in general they don't provide } \\
\text { support for cafeteros. Seem satisfied with prices of coffee for organics. }\end{array}$ \\
\hline Socio-economic limitations & $\begin{array}{l}\text { Previous projects on the landscape never returned results, farmers wanted recognition and knowledge of } \\
\text { programs. Want other crops and express interest in ecotourism. Want to sell coffee directly to consumer } \\
\text { avoiding filters of organizations or associations. }\end{array}$ \\
\hline Infrastructure & $\begin{array}{l}\text { Improve cellular network and roads. Better coffee technology, including filters for wastewater and } \\
\text { transportation so that they don't harm the environment. }\end{array}$ \\
\hline $\begin{array}{l}\text { Moderator observations from } \\
\text { focal groups discussions }\end{array}$ & $\begin{array}{l}\text { Decisions farmers make are ultimately about coffee prices. Coffee farmers don't know what to do about } \\
\text { jaguars - they want to conserve them but they are a nuisance that eat animals such as mules, dogs, and } \\
\text { goats. Very interested in coffee filters for waste water and certifications. They would like to sell their } \\
\text { coffee already processed and remove the middle man. }\end{array}$ \\
\hline
\end{tabular}


Table A2.5 The community of Vista Nieve $(n=8)$ presented here.

\begin{tabular}{|c|c|}
\hline Subcategories & Vista Nieve \\
\hline Biodiversity \& Wildlife & $\begin{array}{l}\text { Biodiversity is several species of animals and diversity of crops. All animals are found here: mammals } \\
\text { (monkeys, foxes, puma, jaguar), birds (parrot, Santa Marta Parakeet), snakes (endemics } 2-3 \mathrm{spp} \text { ), } \\
\text { amphibians (streams are where frogs are, find them more at night; different varieties - glass frogs and a } \\
\text { red frog). CorpaMag (the environmental authority) brought invasive species. }\end{array}$ \\
\hline Climate Change & $\begin{array}{l}\text { Changes in temperature (increase) and precipitation levels, new climate conditions favor damaging } \\
\text { beetle borer (broca). Changes in species interactions (specifically with two birds, chupahuevo and bi- } \\
\text { colored wren). Coffee cannot produce as well as previously. }\end{array}$ \\
\hline Value of Land & $\begin{array}{l}\text { Water, conservation, rivers and streams. Reforestation and desire for no contamination (trash has not } \\
\text { been removed in one year). }\end{array}$ \\
\hline Coffee Certifications & $\begin{array}{l}\text { Certificates: rain forest alliance (bird-friendly). Trainings through certification organizations which teach } \\
\text { farmers to take care of the soil and streams and management of sewage water. } 4 \text { organic farms in focus } \\
\text { group. Organics - no chemicals, burning, or fumigating (use machetes to clear understory). Government: } \\
\text { supports them but they can't do anything to get higher prices. The committee of cafeteros supports them } \\
\text { a lot (specifically, caficosta). Organics: want to take care of the environment and also have income } \\
\text { bonus for higher coffee prices; non-organics can produce more coffee/year. Negative to non-organic is } \\
\text { the soil becomes infertile rapidly. Coffee prices are low. }\end{array}$ \\
\hline Socio-economic limitations & $\begin{array}{l}\text { Government doesn't support farmers with higher prices, but FNC and caficosta (cooperative) is } \\
\text { supportive. Worry about coffee prices and kids interest in coffee (moto taxis vs coffee growing). Very } \\
\text { mad with CorpaMag who has not cleared trash in }>1 \text { year. Local-level corruption (bribes with } \\
\text { community leaders). They want to increase entities with more sense of belonging, support for children's } \\
\text { education. Want help to reforest including incentives. }\end{array}$ \\
\hline Infrastructure & Better cellular network and schools. \\
\hline $\begin{array}{l}\text { Moderator observations from } \\
\text { focal groups discussions }\end{array}$ & $\begin{array}{l}\text { Many complaints about the local environmental authority (CorpaMag). Don't want to be taken advantage } \\
\text { of; interested in differences between organics and non-organics. }\end{array}$ \\
\hline
\end{tabular}

